\title{
Building control (amendment) regulations 2014: integration and compliance in large Irish construction organisations
}

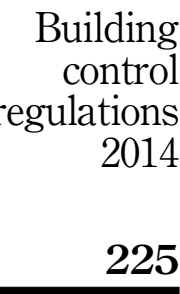

Received 29 April 2021 Revised 23 August 2021 Accepted 15 September 2021

\begin{abstract}
Purpose - The purpose of this study is to identify the factors relating to the integration and compliance of Building Control (Amendment) Regulations 2014 (BC(A)R 2014) in large Irish construction organisations.

Design/methodology/approach - To achieve the aim, a mixed method approach is adopted, initially, providing a critique of the literature review, followed by a combination of 7 semi-structured interviews and 30 questionnaires from industry practitioners.

Findings - Findings demonstrate that $\mathrm{BC}(\mathrm{A}) \mathrm{R}$ has had a significant positive effect on the industry, eliminating previous bad practice, by increasing the accountability for professionals signing-off on new buildings, and highlights the emphasis on certification in successfully achieving practical completion on projects.

Practical implications - The findings provide further justification on the need for compliance, and integration, of $\mathrm{BC}(\mathrm{A}) \mathrm{R}$ in the Irish construction sector, offering further evidence, where needed, on the benefit of its adoption.

Originality/value - The originality and value of this research lies in the limited number of studies in the area, particularly in the context of large Irish construction projects, which this study aims to fulfil.
\end{abstract}

Keywords BC(A)R, Regulatory system, Certification

Paper type Research paper

\section{Introduction}

The international construction industry underpins the competitiveness and productivity of the respective domestic economy in which it is placed, by providing and maintaining the infrastructure necessary for it to function (Construction Industry Federation, 2019). Ireland is no different and cannot grow without the success of its construction industry, as it provides the office space we work in, the housing we live in and the infrastructure we travel on (McGrath, 2018). Ensuring Ireland has a dynamic construction industry, with the capacity to deliver construction projects efficiently and cost-effectively is critical (Construction Industry Federation, 2019). A key aspect of the dynamic Irish construction sector is its building regulations. These are a set of legal requirements for the design and construction of new buildings, extensions, material alterations to and specific change of use of existing buildings. The building regulations' primary purpose is to underpin good building practice, in the interests of health, safety and welfare of people using these structures. Building control regulations provide for matters of procedure, administration and control, for the purposes of securing the implementation of the requirements of the building regulations, demonstrating how compliance with such requirements has been achieved in relation to the building or

(C) Gavin Dennehy, Bobby Kennedy and John Spillane. Published by Emerald Publishing Limited. This article is published under the Creative Commons Attribution (CC BY 4.0) licence. Anyone may reproduce, distribute, translate and create derivative works of this article (for both commercial and noncommercial purposes), subject to full attribution to the original publication and authors. The full terms of this licence may be seen at http://creativecommons.org/licences/by/4.0/legalcode

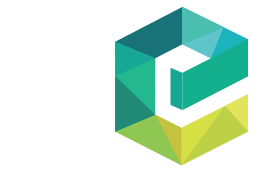

International Journal of Building Pathology and Adaptation Vol. 41 No. 1, 2023 pp. 225-237

Emerald Publishing Limited DOI 10.1108/IJBPA-04-2021-0063 
IJBPA 41,1 works concerned (Department of Housing, Planning, Community and Local Government, 2016). The Building Control (Amendment) Regulations 2014, or $\mathrm{BC}(\mathrm{A}) \mathrm{R}$, as it is more commonly referred to, came into effect on the 1st of March 2014 and has brought about significant change to the building control regime in Ireland (Compton and Keaveney, 2016). $\mathrm{BC}(\mathrm{A}) \mathrm{R} 2014$ 's intend is to focus all parties on compliance with building regulations, from the inception of the works, by requiring the development of an inspection plan at the earliest stages, and having all parties formally acknowledge their respective roles from the outset (Mahony, 2014).

Previous research by Compton and Keaveney (2016) and Monahan (2015) highlight BC(A)R from the perspective of small-scale construction projects and one-off housing. This is as opposed to large-scale projects, in the context of the Irish construction industry. Large-scale projects come with more complexities, higher budgets and larger investment (Lorek, 2018); further evidencing the need to address this gap.

Tan (2020) argues, to achieve project success in large-scale construction projects, it is important for the parties to understand the contractual and legal requirements, while establishing an integrated project control system at the outset. In 2018 alone, the Irish construction industry had over 150 projects under construction, each valued in excess of $€ 20 \mathrm{~m}$. This level of large project development has continued to grow, with over 200 large projects $(\geq € 20 \mathrm{~m})$ at various stages of the project lifecycle (Department of Public Expenditure and Reform, 2019). For the purposes of this study, a large-scale contractor is identified as being above the requirements of a small to medium enterprise (SME); thus, meeting the requirements of a large organisation, as set out by Enterprise Ireland (2007) and came into effect from 1st of January 2005. This therefore then includes construction organisations who operate in Ireland, employing more than 250 employees and having a turnover greater than $€ 50 \mathrm{~m}$.

To address the need for conformity to the respective building regulations, it is essential that $\mathrm{BC}(\mathrm{A}) \mathrm{R}$ is not only complied with, but integrated into these large-scale construction projects in Ireland. This paper comprises a critique of the literature, followed by 7 semistructured interviews, which are complemented by 30 industry questionnaires. This provides the base on which to assess both the integration and compliance of large Irish construction organisations with $\mathrm{BC}(\mathrm{A}) \mathrm{R} 2014$, while also contrasting $\mathrm{BC}(\mathrm{A}) \mathrm{R}$ with previous regulations prior to 1st March 2014.

\section{The building control (amendment) regulations 2014}

Construction involves the production of large-scale capital assets which affect not only the client, designers and constructors, but also users, the public and the environment at large (Cunningham, 2013). The BC(A)R were introduced to improve on the inadequacies of the pre$\mathrm{BC}(\mathrm{A}) \mathrm{R}$ system of Building Control Regulations in the Irish construction sector (Harrington, 2017). As Harrington (2017) outlines, the construction industry in Ireland was first introduced to building control legislation through the Building Control Act 1990. The Building Control Act 1990 is the basis of Building Control in Ireland and it sought to ensure that every structure to which building regulations apply, shall be designed and constructed, in accordance with the provisions of such regulation, while aiming to promote good practice in the design and construction of buildings, in the interests of health, safety and welfare of persons who use such buildings. Essentially, as noted by Compton and Keaveney (2016), the Building Control Act 1990 saw the introduction and development of Building Regulations, Building Control Regulations and Building Control Authorities. In addition, Harrington (2017) observes that to facilitate this statutory requirement and to indicate how the various requirements of the Building Control Act 1990 could be achieved in practice, a series of Technical Guidance Documents were produced. Furthermore, regarding the Technical 
Guidance Documents, adherence to the various approaches outlined is regarded as evidence of compliance with the requirements of the relevant part of the Building Regulations (Harrington, 2017). Compton and Keaveney (2016) state that the Building Control Act 2007 was introduced to both amend and extend the Building Control Act 1990. However, until the introduction of the $\mathrm{BC}(\mathrm{A}) \mathrm{R} 2014$, they also declare that the system in place of regulating buildings in Ireland, did not include statutory certificates of compliance issued by local authorities, but one which provided an opinion on compliance by the designer employed by the consumer. Prior to $\mathrm{BC}(\mathrm{A}) \mathrm{R}$, the system of certification on Irish construction projects was self-certification. Hollingsworth (2014, p. 1) observes that "self-certification largely pertained to conveyance and generally confirmed that there was substantial compliance with the building regulations, as opposed to ensuring that all building standards were fully met". The new building control regime is underpinned by a system of statutory certification and as a result, improves compliance with the Building Regulations, which was envisaged by the Building Control Act 1990.

Within the Irish construction sector, what started as a proportionate response to increased demand for property in the late 1990s, rapidly progressed to an unsustainable property bubble, with substantial over-building by the mid-2000s (Forfás, 2013). The Society of Chartered Surveyors Ireland (2012) reveals that the Irish construction industry peaked at close to $€ 39 \mathrm{bn}$; almost $25 \%$ of Ireland's Gross National Product in 2006. Throughout the growth period of 2003-2006, inadequate building control measures were in place. A culture of non-compliance to building regulations resulted in publicised cases involving defective materials and unsatisfactory workmanship (Compton and Keaveney, 2016). As Monahan (2015) highlights, this resulted in a review and eventual overhaul of the certification method for any project in the Irish construction sector, through the Building Control (Amendment) Regulations 2014. The Department of the Environment, Community and Local Government (2014) affirm that the aim of $\mathrm{BC}(\mathrm{A}) \mathrm{R}$ is to ensure that all involved in the construction process and the regulatory system, work effectively to achieve better building outputs.

Mandal (2014) declares that the building regulations themselves did not change, but rather the process by which compliance, or more significantly, non-compliance with the regulations is controlled. According to Harrington (2017), the stringent system imposed on the Irish construction sector under $\mathrm{BC}(\mathrm{A}) \mathrm{R}$, sought to create a system of checks and balances to ensure compliance with regulations. Monahan (2015) observes that the new regulations require several documents to be forwarded to the relevant building authority, all of which is managed on a new system, namely the "Building Control Management System". The Local Government Management Agency (2016) states that the Building Control Management System acts as the preferred means of electronic building control administration. The system was also implemented in March 2014, in line with BC(A)R, and allows property owners, builders, developers, architects and engineers to submit notifications, applications and compliance certificates, digitally. All projects must be registered on the platform. As emphasised by the Society of Chartered Surveyors Ireland (2016), BC(A)R requires statutory appointments, statutory duties and statutory certificates, giving rise to the provision of additional tasks and additional services. Compton and Keaveney (2016) note that the key changes introduced by the revised regulations include, mandatory design certification by a design certifier, compulsory inspection by an appointed assigned certifier, building supervision and certification, and submission of plans and particulars. The Society of Chartered Surveyors Ireland (2016) state, both the design and assigned certifiers, are required to be registered architects, engineers or building surveyors. The design certifier is responsible for carrying out their design and co-ordinating any design activities of others for the works concerned. The design certifier completes and signs the statutory "Certificate of Compliance (Design)" at the commencement notice stage, and thereafter, they may become an ancillary certifier for any design changes, deferred elements and/or variations that take place to their 
IJBPA

41,1

design. The "Assigned Certifier" is defined as a competent, registered professional person, assigned by the Building Owner (Client) to inspect, and certify works in accordance with the Building Control Regulations as clarified by the Department of Housing, Planning, Community, and Local Government (2016). They further state that assigned certifiers are tasked with preparing an inspection plan, to be implemented by both themselves and others, during construction, so they can sign the "Certificate of Compliance on Completion". The statutory certification required under the new regulations is of the utmost importance, particularly the Certificate of Compliance on Completion. Compton and Keaveney (2016) also note that compliance with the provisions of the new regulations is of importance for building owners, purchasers or prospective tenants, because the regulations prohibit the opening, occupation or use of a building, until a certificate of compliance on completion has been filed and registered by the Building Control Authority. The certificate of compliance on completion produced jointly by the assigned certifier and the main contractor, also stands as an imperative milestone which must be addressed, prior to handing over a project through $\mathrm{BC}(\mathrm{A}) \mathrm{R}$.

The new regulations have had considerable effect on the way building design and construction are both managed and executed in Ireland. Competent professionals now have greater control of inspections and provide a chain of responsibility throughout the design and construction process.

Irish construction firms have become accustomed to carrying out business in a manner that has evolved over decades, but, as McDonnell (2016) outlines, this comes with the challenge in changing that culture. As Monahan (2015) argues, the scope requirement for any construction project is that at completion, the building is built in compliance with building regulations and in accordance with the designers' drawings, calculations and specifications. Ahern et al. (2018) attributes the perceived improvement in compliance in the Irish construction industry due to $\mathrm{BC}(\mathrm{A}) \mathrm{R}$ 's integration, may be credited to the number of active certifiers increasing, in addition to site supervision inspections, due to the risk of litigation from compliance certification.

Baiche et al. (2006) further this by arguing that there are numerous areas where building regulation non-compliance can be found. They suggest that poor workmanship, ignorance of details or regulations, poor management, use of incorrect or non-certified materials, conflict or confusion between trades, the pressure to complete work, changes to approved designs, unfamiliarity with design, complicated labour-intensive details and lack of detailed calculations are all factors contributing to non-compliance. However, Baiche et al. (2006) argue that site operatives and site management have the responsibility for non-compliance, and certifiers should not be enforcers, but instead should be focused on verifying that the respective construction conforms to the respective regulations and codes of practice. Ahern et al. (2018) reaffirm that complying with building regulations in Ireland has improved, due to the design and construction compliance requirements, the increased amount of supervision and inspections, the level of accountability and certification required by all involved in the design and construction process, and the risk of litigation from certification misrepresentation. However, Monahan (2015) adds a note of caution, in that one of the issues with $\mathrm{BC}(\mathrm{A}) \mathrm{R}$ is that the building control authorities are not required to perform technical assessments of compliance with building regulation, at the commencement or completion stage. If a technical assessment of compliance were to be conducted by the building control authority, at the commencement and completion stages for all projects, this would constitute a second level check to capture non-compliance. O'Connor (2014, p. 1) states that "building owners are usually driven by project cost" while Heneghan and Byrne (2014, p. 1) alleges, it is likely that costs will increase, but they are hopeful "that the Regulations will play an important role in the pursuit of an improved culture of building control with an increased focus on care and safety in the construction industry". 


\section{Research design}

To investigate the integration and subsequent compliance of $\mathrm{BC}(\mathrm{A}) \mathrm{R} 2014$ within large-scale organisations in the Irish construction industry, data are gathered through a mixed-method research approach. This encompasses an informative literature review of $\mathrm{BC}(\mathrm{A}) \mathrm{R}, 7$ semistructured interviews, followed by an industry-oriented questionnaire survey. Silverman (2017) emphasises that the choice of research method should be focused on the most apt approach in addressing the aim in question. Given the need to gain industry insight, both interviews and questionnaires provide an opportunity to address this, by gaining a deep insight and industry wide perspective, respectively.

Through the semi-structured industry interviews, this provided the opportunity to gain detailed and in-depth knowledge and awareness, while also providing an opportunity to unearth further factors, which are not identified in the literature. To identify and shortlist appropriate candidates to participate in the study, necessary criteria is drawn up and summarised as follows:

(1) Currently working in the Irish construction industry.

(2) A minimum of three years' experience in the sector.

(3) Work in an Irish large-scale organisation; employing more than 250 employees and having a turnover greater than $€ 50 \mathrm{~m}$ per annum.

(4) Currently employed within the Construction Industry Federation's (CIF) top 12 list of construction contractors.

(5) Be available and amenable to participate in the research.

Seven of the interviewees are employed within the private sector and include a regional engineer (\#1), a document controller (\#2), a senior engineer (\#3), a quality manager (\#4), a construction manager (\#5), a digital manager (\#6) and a project manager (\#7). Interviewees have, on average, 11-15 years of experience in their respective roles. Interviewing knowledgeable industry professionals in relation to their large Irish construction organisations $\mathrm{BC}(\mathrm{A}) \mathrm{R}$ practices, is a key aspect, focussing at both an organisational and project level. The authors compiled a list of factors which emanated from the literature and used as guidance for discussion with interviewees, as opposed to a strict protocol to be followed in each interview. Their order and use may vary between interviews, depending on the flow of the conversation (Saunders and Tornhill, 2016). The interview protocol applied is designed with the aim of investigating the integration and compliance of $\mathrm{BC}(\mathrm{A}) \mathrm{R}$ within each of the respective participant's organisations. The semi-structured interview format chosen, determines people's subjective reactions to situations; thus, extending the researcher's knowledge on the topic (McIntosh and Morse, 2015). The interviews are recorded using shorthand note taking, with accompanying mind maps, to document the interviewees' responses. The results of each interview are analysed using thematic coding, firstly in Microsoft ${ }^{\mathrm{TM}}$ Excel $^{\mathrm{TM}}$, where each of the factors is noted in a separate line and cell. Each of the seven interviews is analysed in this manner, with the results merged and repetitive factors consolidated. The results are also displayed in a mind map for each of the interviews, to aid in the identification of core and overlapping factors.

To supplement this, an industry wide survey in the form of an online questionnaire is developed, using the factors extracted from the interviews, in conjunction with those identified in the literature, to obtain a wider perspective of professionals across the country. Groves et al. (2009) describe a survey as a systematic method for gathering information from entities, to construct quantitative descriptors of the attributes of the larger population of which the entities are members. The quantitative research component includes the use of a
Building

control regulations 2014 
IJBPA

41,1

questionnaire survey, directed at project managers, quality managers, quantity surveyors, construction managers, engineers and architects, within large-scale organisations in the Irish construction sector. The questionnaire consists of 29 factors, split between integration (16) and compliance (13). This is then circulated, electronically, to individuals and firms that fit within the parameters of the research outlined previously. Each of the factor responses are captured using a five-point Likert scale. A Likert scale is a psychometric scale that has multiple categories from which respondents choose to indicate their opinions, attitudes or feelings about a particular issue (Nemoto and Beglar, 2014). The five point scale applied is as follows: Strongly Disagree (1), Disagree (2), Neither Disagree nor Agree (3), Agree (4) and Strongly Agree (5). This allows the authors to attain objective information on industry specialists' perspectives and knowledge of the revised regulations, in terms of integration and subsequent compliance (Compton and Keaveney, 2016).

From an ethical perspective, the participants are informed of the nature of the research, its purpose and what the collective data will be used for, prior to the commencement of interviews and questionnaires. The resultant questionnaire data are then used to identify leading factors for the integration and compliance of BC(A)R 2014 in large construction organisations in Ireland.

\section{Results and analysis}

The interviews commenced by gaining general background information from each participant, followed by a discussion on $\mathrm{BC}(\mathrm{A}) \mathrm{R}$ 's integration and subsequent compliance within their respective Irish large-scale organisation. A key aspect from the interview analysis highlights that interviewees have similar experiences and opinions on the integration and compliance of $\mathrm{BC}(\mathrm{A}) \mathrm{R}$ within their respective organisations, regardless of who their employer is. Tables 1 and 2 document the integration and compliance factors respectively, noting, where applicable, the respective literature and associated interviewee(s) who referred to each of the respective factor.

Subsequently, using the factors identified in both the literature and the interviews, a questionnaire is developed and distributed electronically, to industry professionals that meet the criteria outlined above. In total, 30 respondents from Irish large-scale organisations are returned, recorded and analysed. The respondents consisted of seven quality managers, seven engineers, six quantity surveyors, five project managers, two construction managers, two site managers and one foreman. Using a five-point Likert scale, respondents indicated their opinions, allowing for analysis of results and calculation of the mean responses to each question posed, where the results are displayed in rank order, as per Table 3.

\section{Discussion}

From the results of the literature review, interviews and resultant questionnaire survey, and the subsequent rank order of factors, first, integration is discussed, followed by compliance, as follows.

\section{Integration}

All seven interviewees agree that the integration of $\mathrm{BC}(\mathrm{A}) \mathrm{R}$ brings about significant changes within an organisation building control regime; a sentiment echoed by Compton and Keaveney (2016). All interviewees also agree with the Department of the Environment, Community and Local Government (2014), that the integration of $\mathrm{BC}(\mathrm{A}) \mathrm{R}$ ensures that all involved in the construction process and the regulatory system, work effectively to achieve better building construction; $80 \%$ of questionnaire respondents are also in agreeance. A common theme across the interviews, which is reiterated by Mahony (2014), is the 


\begin{tabular}{|c|c|c|c|c|c|c|c|c|c|}
\hline & & Inter & view & & & & & & Building \\
\hline Integration factor & Literature & $\# 1$ & $\# 2$ & $\# 3$ & $\# 4$ & $\# 5$ & $\# 6$ & $\# 7$ & control \\
\hline $\begin{array}{l}\text { The integration of } \mathrm{BC}(\mathrm{A}) \mathrm{R} \text { brings } \\
\text { about significant changes in } \\
\text { organisations building control } \\
\text { regime }\end{array}$ & $\begin{array}{l}\text { Compton and Keaveney } \\
(2016)\end{array}$ & $\mathrm{x}$ & $\mathrm{x}$ & $\mathrm{x}$ & $\mathrm{x}$ & $\mathrm{x}$ & $\mathrm{x}$ & $\mathrm{x}$ & 2014 \\
\hline $\begin{array}{l}\mathrm{BC}(\mathrm{A}) \mathrm{R} \text { is the result of a reviewed } \\
\text { and overhauled certification method } \\
\text { for any project in the Irish } \\
\text { construction sector }\end{array}$ & Monahan (2015) & $\mathrm{x}$ & $\mathrm{x}$ & $\mathrm{x}$ & $\mathrm{x}$ & $\mathrm{x}$ & $\mathrm{x}$ & $\mathrm{x}$ & 231 \\
\hline $\begin{array}{l}\text { The integration of } \mathrm{BC}(\mathrm{A}) \mathrm{R} \text { ensures } \\
\text { that all involved in the construction } \\
\text { process and their regulatory system } \\
\text { work effectively to achieve better } \\
\text { building construction }\end{array}$ & $\begin{array}{l}\text { Department of the } \\
\text { Environment, Community, } \\
\text { and Local Government } \\
\text { (2014) }\end{array}$ & $\mathrm{x}$ & $\mathrm{x}$ & $\mathrm{x}$ & $\mathrm{x}$ & $\mathrm{x}$ & $\mathrm{x}$ & $\mathrm{x}$ & \\
\hline $\begin{array}{l}\mathrm{BC}(\mathrm{A}) \mathrm{R} \text { requires statutory } \\
\text { appointments, statutory duties and } \\
\text { statutory certificates given rise to } \\
\text { the provision of additional tasks and } \\
\text { additional services }\end{array}$ & $\begin{array}{l}\text { Society of Charted } \\
\text { surveyors Ireland (2016) }\end{array}$ & $\mathrm{x}$ & & $\mathrm{x}$ & $\mathrm{x}$ & $\mathrm{x}$ & $\mathrm{x}$ & $\mathrm{x}$ & \\
\hline $\begin{array}{l}\text { The intention of the } 2014 \text { regulations } \\
\text { is to focus all parties on compliance } \\
\text { with building regulations from the } \\
\text { inception of the works }\end{array}$ & Mahony (2014) & $\mathrm{x}$ & & $\mathrm{x}$ & $\mathrm{x}$ & $\mathrm{x}$ & $\mathrm{x}$ & $\mathrm{x}$ & \\
\hline $\begin{array}{l}\text { Site managers and supervisors } \\
\text { undertook training designed to } \\
\text { provide them with an understanding } \\
\text { of their role in achieving compliance } \\
\text { with current legislation }\end{array}$ & $\begin{array}{l}\text { Construction Industry } \\
\text { Federation (2018) }\end{array}$ & & & & & & & & \\
\hline $\begin{array}{l}\text { Building control officer brought into } \\
\text { organisation on consultancy basis to } \\
\text { aid } \mathrm{BC}(\mathrm{A}) \mathrm{R} \text { integration }\end{array}$ & $\begin{array}{l}\text { National Building Control } \\
\text { Office (2019) }\end{array}$ & & & & $\mathrm{x}$ & & & $\mathrm{x}$ & \\
\hline $\begin{array}{l}\text { Requires the development of an } \\
\text { inspection plan at the earliest stages } \\
\text { of a construction project }\end{array}$ & Mahony (2014) & $\mathrm{x}$ & $\mathrm{x}$ & $\mathrm{x}$ & $\mathrm{x}$ & $\mathrm{x}$ & $\mathrm{x}$ & $\mathrm{x}$ & \\
\hline $\begin{array}{l}\text { Building control management } \\
\text { system acts as the preferred means } \\
\text { of electronic building control } \\
\text { administration and is a key aspect of } \\
\text { BC(A)R's integration }\end{array}$ & $\begin{array}{l}\text { Local Government } \\
\text { Management Agency (2016) }\end{array}$ & & & & $\mathrm{x}$ & $\mathrm{x}$ & & $\mathrm{x}$ & \\
\hline $\begin{array}{l}\mathrm{BC}(\mathrm{A}) \mathrm{R} \text { compliant workflow } \\
\text { managed through BIM }\end{array}$ & & $\mathrm{x}$ & $\mathrm{x}$ & $\mathrm{x}$ & $\mathrm{x}$ & & $\mathrm{x}$ & & \\
\hline $\begin{array}{l}\text { The integration process involves all } \\
\text { parties formally acknowledging } \\
\text { their respective roles from project } \\
\text { inception through to project } \\
\text { completion }\end{array}$ & Mahony (2014) & $\mathrm{x}$ & $\mathrm{x}$ & $\mathrm{x}$ & $\mathrm{x}$ & $\mathrm{x}$ & $\mathrm{x}$ & & \\
\hline $\begin{array}{l}\text { It is likely that costs will be } \\
\text { increased because of } \mathrm{BC}(\mathrm{A}) \mathrm{R} \\
\text { integration at both organisational } \\
\text { and project level }\end{array}$ & Heneghan and Byrne (2014) & $\mathrm{x}$ & $\mathrm{x}$ & $\mathrm{x}$ & $\mathrm{x}$ & $\mathrm{x}$ & $\mathrm{x}$ & & \\
\hline $\begin{array}{l}\text { There is a lack of } \mathrm{BC}(\mathrm{A}) \mathrm{R} \text { integration } \\
\text { into large-scale fit-outs }\end{array}$ & $\begin{array}{l}\text { Property Industry Ireland } \\
\text { (2018) }\end{array}$ & $\mathrm{x}$ & $\mathrm{x}$ & $\mathrm{x}$ & & & $\mathrm{x}$ & & $\begin{array}{r}\text { Table 1. } \\
\text { Integration factors and } \\
\text { corresponding sources }\end{array}$ \\
\hline
\end{tabular}


IJBPA
41,1

232

Table 2.

Compliance factors and corresponding sources

\begin{tabular}{|c|c|c|c|c|c|c|c|c|}
\hline & & & view & & & & & \\
\hline Integration factor & Literature & $\# 1$ & \#2 & \#3 & \#4 & \#5 & \#6 & \#7 \\
\hline $\begin{array}{l}\text { The building regulations themselves } \\
\text { did not change but rather the } \\
\text { process by which compliance or } \\
\text { more significantly non-compliance } \\
\text { with the regulations is controlled }\end{array}$ & Mandal (2014) & $\mathrm{x}$ & $\mathrm{x}$ & $\mathrm{x}$ & $\mathrm{x}$ & $\mathrm{x}$ & $\mathrm{x}$ & $\mathrm{x}$ \\
\hline $\begin{array}{l}\text { Integrating the stringent system } \\
\text { imposed on the Irish construction } \\
\text { sector under BC(A)R creates a } \\
\text { system of checks and balances to } \\
\text { ensure compliance with regulations }\end{array}$ & Harrington (2017) & $\mathrm{x}$ & $\mathrm{x}$ & $\mathrm{x}$ & $\mathrm{x}$ & $\mathrm{x}$ & $\mathrm{x}$ & $\mathrm{x}$ \\
\hline $\begin{array}{l}\text { The new regulations require several } \\
\text { documents to be forwarded to the } \\
\text { relevant building authority }\end{array}$ & Monahan (2015) & $\mathrm{x}$ & $\mathrm{x}$ & $\mathrm{x}$ & $\mathrm{x}$ & $\mathrm{x}$ & $\mathrm{x}$ & $\mathrm{x}$ \\
\hline $\begin{array}{l}\text { Assigned certifiers are tasked with } \\
\text { preparing an inspection plan to be } \\
\text { implemented by themselves and } \\
\text { others during construction in order } \\
\text { that they are able to sign the } \\
\text { certificate of compliance on } \\
\text { completion }\end{array}$ & $\begin{array}{l}\text { Department of Housing, } \\
\text { Planning, Community and } \\
\text { Local Government (2016) }\end{array}$ & $\mathrm{x}$ & $\mathrm{x}$ & $\mathrm{x}$ & $\mathrm{x}$ & $\mathrm{x}$ & $\mathrm{x}$ & $\mathrm{x}$ \\
\hline $\begin{array}{l}\text { The regulations prohibit the } \\
\text { opening, occupation or use of a } \\
\text { building until a certificate of } \\
\text { compliance on completion has been } \\
\text { filed and registered by the building } \\
\text { control authority }\end{array}$ & $\begin{array}{l}\text { Compton and Keaveney } \\
\text { (2016) }\end{array}$ & $\mathrm{x}$ & $\mathrm{x}$ & $\mathrm{x}$ & $\mathrm{x}$ & $\mathrm{x}$ & $\mathrm{x}$ & $\mathrm{x}$ \\
\hline $\begin{array}{l}\text { Costs of construction will be } \\
\text { increased to ensure compliance }\end{array}$ & Heneghan and Byrne (2014) & $\mathrm{x}$ & $\mathrm{x}$ & $\mathrm{x}$ & $\mathrm{x}$ & $\mathrm{x}$ & $\mathrm{x}$ & $\mathrm{x}$ \\
\hline $\begin{array}{l}\text { Certificate of completion stands as } \\
\text { an imperative milestone while } \\
\text { handing over a project through } \\
\mathrm{BC}(\mathrm{A}) \mathrm{R}\end{array}$ & RKD Architects (2016) & $\mathrm{x}$ & $\mathrm{x}$ & $\mathrm{x}$ & $\mathrm{x}$ & $\mathrm{x}$ & $\mathrm{x}$ & $\mathrm{x}$ \\
\hline $\begin{array}{l}\text { Neither the building owner, designer } \\
\text { nor builder can be impartial in } \\
\text { certifying their own works }\end{array}$ & $\begin{array}{l}\text { Property Industry Ireland } \\
\text { (2018) }\end{array}$ & & & & & & $\mathrm{x}$ & \\
\hline $\begin{array}{l}\text { There is a clear demand for active, } \\
\text { independent on-site inspections by } \\
\text { local authority personnel }\end{array}$ & $\begin{array}{l}\text { Department of the } \\
\text { Environment, Community, } \\
\text { and Local Government } \\
(2015)\end{array}$ & $\mathrm{x}$ & $\mathrm{x}$ & & & $\mathrm{x}$ & & $\mathrm{x}$ \\
\hline $\begin{array}{l}\text { The establishment of a lead } \\
\text { authority for building control could } \\
\text { serve to provide a consistent } \\
\text { approach to BC(A)R and compliance }\end{array}$ & $\begin{array}{l}\text { Property Industry Ireland } \\
\text { (2018) }\end{array}$ & $\mathrm{x}$ & $\mathrm{x}$ & & & & $\mathrm{x}$ & $\mathrm{x}$ \\
\hline $\begin{array}{l}\text { The building control authorities are } \\
\text { not required to perform technical } \\
\text { assessments of compliance with } \\
\text { building regulation at } \\
\text { commencement or at completion } \\
\text { stage }\end{array}$ & Monahan (2015) & $\mathrm{x}$ & $\mathrm{x}$ & $\mathrm{x}$ & $\mathrm{x}$ & $\mathrm{x}$ & $\mathrm{x}$ & \\
\hline $\begin{array}{l}\text { Competent professionals now have } \\
\text { greater control of inspections and } \\
\text { provide a chain of responsibility } \\
\text { throughout the design and } \\
\text { construction process to ensure } \\
\text { compliance }\end{array}$ & RKD Architects (2016) & $\mathrm{x}$ & $\mathrm{x}$ & $\mathrm{x}$ & $\mathrm{x}$ & $\mathrm{x}$ & $\mathrm{x}$ & \\
\hline
\end{tabular}


$\mathrm{BC}(\mathrm{A}) \mathrm{R}$ ensures that all involved in the regulatory system work effectively achieving better

building construction

There should only be one such means of electronic building control administration

The building control management system acts as the preferred means of electronic building control administration

$\mathrm{BC}(\mathrm{A}) \mathrm{R}$ 's integration into organisations brought about significant changes to their existing building control regime

$\mathrm{BC}(\mathrm{A}) \mathrm{R}$ ensures that all involved in the construction process work effectively achieving better building construction

Integrating $\mathrm{BC}(\mathrm{A}) \mathrm{R}$ into an organisation gives rise to the provision of additional tasks

Integrating $\mathrm{BC}(\mathrm{A}) \mathrm{R}$ into an organisation gives rise to the provision of additional services

Certificate of compliance on completion is an imperative milestone while handing over a project

The establishment of a lead authority for building control could provide a more consistent approach to $\mathrm{BC}(\mathrm{A}) \mathrm{R}$ compliance

$\mathrm{BC}(\mathrm{A}) \mathrm{R}$ provides a chain of responsibility throughout the design process

$\mathrm{BC}(\mathrm{A}) \mathrm{R}$ provides a chain of responsibility throughout the construction process

$\mathrm{BC}(\mathrm{A}) \mathrm{R}$ allows competent professionals greater control of inspections to ensure compliance

Technical assessment of compliance should be conducted by building control authority at commencement and completion stages

The building regulations themselves did not change but rather the process of compliance by which the regulations are controlled

Ireland is the only developed country where a designer/builder may certify their own works without independent oversight, this needs reform

A second level check by the building control authority would capture most non-compliances

There is a clear demand for active independent on-site inspections by local authority personnel

An organisations compliance with $\mathrm{BC}(\mathrm{A}) \mathrm{R}$ on projects has been assessed by building control

The building owner, designer nor builder can be impartial in certifying compliance of their own works

Table 3.

Integration and compliance factors in rank order based on questionnaire results

requirement of the development of an inspection plan at the earliest stages of a project. A reoccurring theme across all interviews is the significance of the appointment of an assigned certifier. Interviewee \#4 highlights the importance of the assigned certifier, giving the main contractor a preliminary inspection plan on project commencement; a viewpoint reiterated by interviewee \#2 and \#5. Doing this, begins the process of regularly updating the inspection plan register throughout the project duration. There is a consistent description and a clear 
IJBPA

41,1

understanding of the role of the assigned certifier across all interviewees. This verifies Mahoney's (2014) statement, where the integration process involves all parties formally acknowledging their respective roles, from project inception through to project completion.

A key aspect of $\mathrm{BC}(\mathrm{A}) \mathrm{R}$ 's integration is the procurement route of a project. All interviewees provide examples of how a procurement route affects $\mathrm{BC}(\mathrm{A}) \mathrm{R}$ practices. The traditional procurement route, where design and build are two distinct and separate elements, requires the client to appoint the assigned certifier, which is the case for most large-scale construction projects. However, the interviewees declare that in the design and build (D\&B) procurement route, the client remains responsible for the appointment of the assigned certifier. In addition to this, in large-scale projects, the assigned certifier should not fulfil the same role as the design certifier, which $80 \%$ of questionnaire respondents agree. As identified by Heneghan and Byrne (2014), it is likely that costs will be increased because of BC(A)R integration, at both organisational and project levels. This is a statement in which both interviewees and questionnaire respondents agreed with. Interviewee \#7 recognises that there is significant cost and time element associated with $\mathrm{BC}(\mathrm{A}) \mathrm{R}$, who, along with interviewee $\# 1$ and $\# 6$, see this as a positive allocation of project funds and time.

Further to this, the Construction Industry Federation (2018) argue that site managers and supervisors are required to undertake training, designed to provide them with an understanding of their role, in achieving compliance with current legislation. On the contrary, $58 \%$ of questionnaire respondents disagree with the statement that all personnel involved in the organisations building control regime have adequate $\mathrm{BC}(\mathrm{A}) \mathrm{R}$ training. However, Interviewee \#7 states that the $\mathrm{BC}(\mathrm{A}) \mathrm{R}$ process is a learning curve and individual training can also come in the form of gaining experience.

Another common theme across all interviewees is the use of a common data environment, in the management of information, where interviewee \#6 stresses that the use of such platforms aids in managing a $\mathrm{BC}(\mathrm{A}) \mathrm{R}$ compliant workflow.

\section{Compliance}

As indicated by Mandal (2014), the building regulations themselves did not change, but rather the process by which compliance, or more significantly, non-compliance with the regulations is controlled; $78 \%$ of questionnaire respondents agreed with this statement. A key aspect emphasised by interviewees is that the quality of work is to a higher standard because of $\mathrm{BC}(\mathrm{A}) \mathrm{R}$. This is due to all elements having to be inspected and signed-off on, by the relevant personnel. Harrington (2017) iterates, in line with the interviewees that, integrating the stringent system imposed under the Irish construction sector enforced by $\mathrm{BC}(\mathrm{A}) \mathrm{R}$, creates a system of checks and balances, to ensure compliance with regulations. Monahan (2015) notes that, building control authorities are not required to perform technical assessments of compliance with building regulations at the commencement or completion stage. However, interviewee \#4 emphasises that assigned certifiers are in direct correspondence with Building Control Authorities. Of the total, $75 \%$ of questionnaire respondents agree that there is a clear demand for active and independent on-site inspections by local authority personnel. As stated by Property Industry Ireland (2018), Ireland is the only country in the developed world, where a designer or builder may certify their works without independent oversight; $76 \%$ of questionnaire respondents are in favour of reforming this aspect. Property Industry Ireland (2018) recognises that the establishment of a lead authority for building control could serve to provide a consistent approach to $\mathrm{BC}(\mathrm{A}) \mathrm{R}$ and compliance, with $86 \%$ of questionnaire respondents agreeing.

Heneghan and Byrne (2014) identify that costs of construction will increase, to ensure compliance. The interviewees recognise that, despite the increased costs of construction, this also aids in an increase in quality and workmanship within the construction process. 
The certificate of completion stands as an imperative milestone, while handing over a project through $\mathrm{BC}(\mathrm{A}) \mathrm{R}$. As $\mathrm{BC}(\mathrm{A}) \mathrm{R}$ leads to increased costs, to ensure compliance while also increasing the quality of workmanship, which in turn results in a smooth handover stage, with minimal rework; thus, contributing to the signing off on the certificate of completion of the assigned certifier. Interviewee \#1 states that, due to the industry continuously adapting and becoming more accustomed to $\mathrm{BC}(\mathrm{A}) \mathrm{R}$, the handover process of projects is now more efficient in recent years, compared to when $\mathrm{BC}(\mathrm{A}) \mathrm{R}$ was first introduced. All interviewees emphasise that ancillary certificates for compliance of work, should be the last document received from the subcontractors before handover. The main contractor should ensure everything is in order, in preparation for practical completion handover, to aid in receiving the certificate of completion. Interviewee \#7, a project manager for one of the country's largest developers, further emphasise this, stating the importance of the assigned certifier signing off on inspections and validation certificates. Significantly, $83 \%$ of questionnaire respondents agree that competent professionals now have greater control of inspections and provide a chain of responsibility throughout the design and construction process to ensure compliance.

\section{Conclusion}

With the Irish construction industry recently noted for poor quality and lack of compliance to building control and associated building regulations, in addition to issues surrounding signoff of completed projects, BC(A)R 2014 came into existence. With previous studies on $\mathrm{BC}(\mathrm{A}) \mathrm{R}$ focussing on SMEs, this study fulfils a gap in knowledge by addressing large construction organisations. In doing so, the study centres on the integration and subsequent compliance of $\mathrm{BC}(\mathrm{A}) \mathrm{R}$ within these large-scale organisations in the Irish construction industry. To garner the necessary information, firstly, the literature on $\mathrm{BC}(\mathrm{A}) \mathrm{R}$ is reviewed, followed by 7 semistructured interviews, which is then culminated in 30 industry-based questionnaire responses. Firstly, in terms of integration, $\mathrm{BC}(\mathrm{A}) \mathrm{R}$ has and will continue to bring about significant change to an organisation's building control regime, while also ensuring that all involved in the construction process and the regulatory system, work effectively to achieve better outputs. However, both the interviewees and questionnaire responses indicate that there is a lack of adequate $\mathrm{BC}(\mathrm{A}) \mathrm{R}$ training within large-scale organisations in the Irish construction industry. However, and on a positive note, the results indicate that $\mathrm{BC}(\mathrm{A}) \mathrm{R}$ has resulted in achieving better quality outputs. Furthermore, with the advent and development of Industry 4.0 and the digitisation of the sector, $\mathrm{BC}(\mathrm{A}) \mathrm{R}$ has also aided in the migration of information from a paper-based medium, to one that is electronic; a trait that is welcomed by both interview and questionnaire respondents alike.

Secondly, in terms of compliance, the establishment of a lead authority for building control is suggested, to provide a more consistent approach to $\mathrm{BC}(\mathrm{A}) \mathrm{R}$ compliance. In addition to this, the research indicates that there is demand amongst industry professionals, for a technical assessment of compliance, to be conducted by the building control authority, at both the commencement and completion stages for all projects. Research results and existing literature support this, in that because of the integration and subsequent compliance of $\mathrm{BC}(\mathrm{A}) \mathrm{R}$, costs have increased at both an organisational and project level. One of the overarching positive aspects which is attributable to $\mathrm{BC}(\mathrm{A}) \mathrm{R}$ is the clear lines of responsibility assigned in both the design and construction process; a sentiment echoed by the interviewees in the study.

The findings from both the interviews and questionnaire surveys are specific to this research; therefore, the generalisability of the results to small and medium Irish enterprises is questionable and warrants further study. There is potential to further develop the findings, as $\mathrm{BC}(\mathrm{A}) \mathrm{R}$ is a relatively new approach, to changing the way large-scale organisations and their projects operate within the Irish construction industry. However, the study concludes with 
IJBPA

41,1

identifying key attributes to, firstly, integration and, secondly, compliance to $\mathrm{BC}(\mathrm{A}) \mathrm{R}$. To ensure that this is the case, the findings note the need for training, where both integration and compliance can be jeopardised, where such initiatives are not undertaken. The interviewees and questionnaire respondents both conclude that the need for further training is essential. Furthermore, there needs to be a distinct separation and impartiality, with a building owner, designer nor builder self-certifying, to ensure independence and unbiased decision-making in the context of $\mathrm{BC}(\mathrm{A}) \mathrm{R}$, particularly in the case of compliance. The findings with respect to compliance and integration will subsequently aid large Irish construction organisations, in the identification of the need and importance, of compliance to $\mathrm{BC}(\mathrm{A}) \mathrm{R}$, and factors which require redress, to minimise challenges and maximise opportunity when doing so.

\section{References}

Ahern, E., Bescos, C.J. and Desai, A. (2018), "Evaluating how Ireland has improved building regulations compliance and energy efficiency", in Elsharkawy, H., Zahiri, S. and Clough, J. (Eds), International Conference for Sustainable Design of the Built Environment, London.

Baiche, B., Walliman, N. and Ogden, R. (2006), "Compliance with building regulations in England and Wales”, Structural Survey, Vol. 24 No. 4, pp. 279-299, doi: 10.1108/02630800610704427.

Compton, K. and Keaveney, M. (2016), "Impact on one-off housing arising from amended building control regulations in Ireland", International Virtual Conference, Slovakia, 21-25 March, University of Zilina, doi: 10.21427/wccs-r261.

Construction Industry Federation (2018), "Careers in construction - building control compliance for site managers/supervisors in Ireland", CIF Training, 7 June 2018, available at: https:// ciftraining.ie/2018/06/careers-in-construction-building-control-compliance-for-site-managerssupervisors-in-ireland/ (accessed 27 October 2020).

Construction Industry Federation (2019), Construction Industry Federation - Pre-budget 2020 Submission, Construction Industry Federation, Dublin.

Cunningham, T. (2013), Factors Affecting the Cost of Building Work - an Overview, Dublin Institute of Technology, Dublin.

Department of Housing, Planning, Community and Local Government (2016), Code of Practice for Inspecting and Certifying Buildings and Works: Building Control Regulations 1997-2015, Department of Housing, Planning, Community and Local Government, Dublin.

Department of Public Expenditure and Reform (2019), Project Ireland 2040 - Ireland's Pipeline of Major Infrastructure Projects, Investment Projects and Programmes Office, Dublin.

Department of the Environment, Community and Local Government (2014), Code of Practice for Inspecting and Certifying Buildings and Works: Building Control Regulations 2014, Department of the Environment, Community and Local Government, Dublin.

Enterprise Ireland (2007), "SME Definition”, available at: https://www.enterprise-ireland.com/en/aboutus/our-clients/sme-definition.html (accessed 24 March 2021).

Forfás (2013), Ireland's Construction Sector: Outlook and Strategic Plan to 2015, Forfás, Dublin.

Groves, R.M., Fowler, F.J. Jr, Couper, M.P., Lepkowski, J.M., Singer, E. and Tourangeau, R. (2009), Survey Methodology, 2nd ed., Wiley, New Jersey.

Harrington, S. (2017), Would the Republic of Ireland Benefit From a Top Down Local Authority Lead Approach to Building Regulation Control and is The Current System Unfit For Purpose in Respect of Dwellings Where Bcar Does Not Apply or Can Be Opted Out of?, Master's Thesis, Technological University Dublin, Dublin.

Heneghan, J. and Byrne, C. (2014), Building Control (Amendment) Regulations 2014 - what You Need to Know, William Fry, Dublin. 
Hollingsworth, K. (2014), Opinion: New Building Regulations Will Add Costs but Also Peace of Mind, The Irish Times, Dublin, Thursday, 27th February.

Local Government Management Agency (2016), Local government Efficiency: Report on the Delivery of the Recommendations of the Local Government Efficiency Review Group 2010-2015, County and City Management Association, Dublin.

Building control regulations 2014

Lorek, S. (2018), "How to compete for bigger construction projects", Constructible, 1 October, 2018.

Mahony, M.L. (2014), "Second time lucky? The building control (amendment) regulations 2014”, Irish Building Magazine, 9 April 2014.

Mandal, R. (2014), RIAI President Welcomes Government Initiative on Construction Permits and Property Registration, RIAI, Dublin.

McDonnell, F. (2016), Main Contractor Selection on Construction Projects When Adapting an Integrated Project Delivery Procurement Strategy within an Irish Context, Master's Thesis, Technological University Dublin, Dublin.

McGrath, C. (2018), Future Growth of the Construction Sector, Surety bonds, Dublin.

McIntosh, M.J. and Morse, J.M. (2015), "Situating and constructing diversity in semi-structured interviews", Global Qualitative Nursing Research, Vol. 2, pp. 1-10, doi: 10.1177/ 2333393615597674.

Monahan, A. (2015), The Effect of the Building Control (Amendment) Regulations 2014 on Small Construction Projects in Ireland, Master0030027s Thesis, Dublin Business School, Dublin.

National Building Control Office (2019), Quarterly Update: National Building Control Management Project, National Building Control Office, Dublin, Issue 1.

Nemoto, T. and Beglar, D. (2014), "Developing likert-scale questionnaires", in Sonda, N. and Krause, A. (Eds.), 39th Annual International Conference on Language Teaching and Learning and Educational Materials Exhibition, Tokyo, pp. 1-8.

O'Connor (2014), News and Insights, Engineers Ireland, 09/12/2014, Engineers Ireland, Dublin.

Property Industry Ireland (2018), BCAR - Recommendations for Reform, Property Industry Ireland, Dublin.

RKD Architects (2016), "Building control amendment regulations", available at: http://www.rkd.ie/ Insights_BuildingControlAmendmentRegulations.php (accessed 10 February 2021).

Saunders, L.M. and Tornhill, A. (2016), Research Methods for Business Students, 7th ed., Pearson Education Limited, Harlow.

Silverman, D. (2017), Doing Qualitative Research, 5th ed., SAGE Publications, London.

Society of Chartered Surveyors Ireland (2012), The Irish Construction Industry in 2012, DKM Economic Consultants, Dublin.

Society of Chartered Surveyors Ireland (2016), A Guide to the Building Control (Amendment) Regulations 2014 for Chartered Project Management Surveyors, Society of Chartered Surveyors Ireland, Dublin.

Tan, Y. (2020), Large-scale Construction Project Management, Taylor \& Francis Group, Boca Raton, Florida.

\section{Corresponding author}

John Spillane can be contacted at: John.Spillane@ul.ie

For instructions on how to order reprints of this article, please visit our website:

www.emeraldgrouppublishing.com/licensing/reprints.htm

Or contact us for further details: permissions@emeraldinsight.com 